\title{
Model Analisis Faktor Sebaran Data Curah Hujan Tahunan
}

\author{
Riki Chandra Wijaya ${ }^{1 *}$, Umboro Lasminto ${ }^{2}$ \\ ${ }^{1}$ Jurusan Teknik Sipil, FT Universitas Lampung, Bandar Lampung \\ ${ }^{2}$ Jurusan Teknik Sipil, FT Institut Teknologi Sepuluh Nopember, Surabaya \\ e-mail: ${ }^{1{ }^{*}}$ riki.chandra@eng.unila.ac.id,${ }^{2}$ Umboro_Lasminto@gmail.com \\ Received 07 Desember 2019; Reviewed 20 April 2020; Accepted 27 Mei 2020 \\ Journal Homepage: http://jurnal.borneo.ac.id/index.php/borneoengineering
}

\begin{abstract}
Rainfall occurs in Watershed (DAS) has a special relationship. Data distribution from measuring devices at several locations in the watershed is predicted to have patterns and close relationships. To know this we need a model to be able to show a relationship between measured rainfall data. This research, a factor analysis model is performed to calculate how much the relationship between rainfall data in the watershed and to determine the shape of rainfall distribution patterns that occur. Based on the calculation results, it is known that pattern of rainfall data distribution from 6 rain stations in Bengawan Solo watershed, namely doplang, randu, menden, kedung, japah, and sambong in 1998 has the same distribution pattern. However, the amount of rain height is different. In addition, the maximum Pearson correlation coefficient is 0.536 at Menden-Randu station. While the minimum Pearson correlation value for the Menden-Sambong station is 0.012. This difference is influenced by the distance between Menden-Randu and Menden-Sambong stations. Based on calculations on the factor analysis model, there are two factors that affect directly between these stations. Factor 1 has coefficient value $<0.5$ while factor 2 has 2 values $>0.5$. Based on calculations show that rainfall that occurs in each region does not have a strong relationship between one another, but the occurrence of rain that occurs has the same distribution pattern. From this, it provides information that the pattern of rainfall distribution each year is the same due to the occurrence of rain following climate patterns in global area coverage.
\end{abstract}

Keywords: Factor Analysis Models, Rainfall Data, Data Distribution

\begin{abstract}
Abstrak
Curah hujan yang terjadi dalam suatu Daerah Aliran Sungai (DAS) memiliki suatu hubungan khusus. Sebaran data dari alat ukur pada beberapa lokasi dalam DAS diprediksi memiliki pola dan hubungan yang erat. Untuk mengetahui hal ini diperlukan suatu model agar dapat menunjukkan hubungan antara data curah hujan yang terukur. Dalam penelitian ini, dilakukan model analysis factor untuk menghitung seberapa besar keterkaitan data curah hujan dalam DAS serta untuk mengetahui bentuk pola distribusi curah hujan yang terjadi. Berdasarkan hasil perhitungan diketahui pola distribusi data curah hujan dari 6 stasiun hujan di DAS Bengawan Solo yaitu doplang, randu, menden, kedung, japah, dan sambong pada tahun 1998 memiliki pola distribusi yang sama. Akan tetapi, besaran tinggi hujan berbeda. Selain itu, besar koefisien korelasi Pearson maksimum 0,536 pada stasiun Menden-Randu. Sedangakan nilai korelasi Pearson minimum untuk stasiun Menden-Sambong sebesar 0,012. Perbedaan ini dipengaruhi jarak antar stasiun Menden-Randu dan Menden-Sambong. Berdasarkan perhitungan pada model analysis factor menunjukkan terdapat 2 faktor yang mempengaruhi secara langsung antara stasiun tersebut. Faktor 1 memiliki nilai koefisien $<0,5$ sedangkan factor 2 memiliki 2 nilainya $>0,5$. Berdasarkan perhitungan menunjukkan bahwa curah hujan yang terjadi pada masing-masing wilayah tidak memiliki keterkaitan yang kuat antara satu dan lainnya, namun kejadian hujan yang terjadi memiliki pola distribusi yang sama. Dari hal ini memberikan informasi bahwa pola distribusi hujan setiap tahunnya sama disebabkan kejadian hujan mengikuti pola iklim dalam cakupan wilayah global.
\end{abstract}

Kata kunci: Model Analisis Faktor, Data Curah Hujan, Sebaran Data Hujan 


\section{Pendahuluan}

Hujan atau nama lainnya presipitasi merupakan peristiwa alam yang terjadi pada atmosphere dari perubahan wujud molekul air yang semula berbentuk awan menjadi cair hingga jatuh ke permukaan bumi. Hujan ditandai terlebih dahulu dengan terbentuknya awan hingga kepadatan tertentu. Apabila awan sudah mencapai tingkat kejenuhan yang tinggi maka awan tersebut akan mencair sehingga jatuhnya air ke permukaan bumi. Awan terbentuk akibat adanya peristiwa evaporasi atau penguapan pada seluruh air di bumi. Sedangkan evaporasi terjadi akibat adanya sumber panas yang memanasi air di bumi agar dapat berubah wujud menjadi uap air. Temperatur tanah merupakan faktor kunci dalam proses di permukaan tanah dan memberikan dampak emisi energi terhadap atmosfere dalam siklus hidrologi (Huang, C.L., Li, X., Lu, L., 2008).

Kuantitas terjadinya hujan pada suatu wilayah tergantung pada jumlah awan yang ada pada wilayah tersebut. Awan bisa saja terbentuk bukan pada wilayah tersebut melainkan dapat juga terbentuk pada wilayah lain yang terbawa oleh pergerakan angin. Secara alamiah jumlah hujan yang terjadi pada suatu wilayah juga terpengaruhi oleh siklus angin di bumi. Selain hal itu, tingkat presipitasi dipengaruhi pula tingkat ekologi yang ada dalam suatu DAS (Xu, 2017). Kondisi lahan pada DAS sangat mempengaruhi tingkat infiltrasi yang terjadi. Hubungan antara Curve Number (CN) dan Qindeks dapat diketahui melalui karakteristik hytograph yang terjadi (Chin, 2018). Variasi iklim, lapisan permukaan tanah dan hubungan antara elemen hidrologi serta data spasial dengan akurasi yang tinggi dalam penginderaan jauh dan GIS (geographic information system) dibutuhkan dalam pengamatan meteorologi (Bieger, K., Hörmann, G., Fohrer, N., 2014).

Perbedaan antara satu hujan yang terjadi pada suatu wilayah terhadap wilayah lain saat ini masih belum diketahui hubungan antar kejadiannya. Untuk menganalisa akan hal ini banyak cara yang dapat dilakukan mulai dari yang sederhana hingga yang kompleks. Pada penelitian ini penulis melakukan uji analisis korelasi antara kejadian hujan pada suatu wilayah terhadap wilayah lain yang terjadi dalam satu pulau. Korelasi ini akan memberikan informasi bahwa seberapa besar korelasi kejadian hujan pada suatu wilayah terhadap wilayah lainnya. Dengan demikian, peneliti dapat mengetahui apakah factor yang terjadi antara satu kejadian hujan terhadap kejadian hujan yang lain.

\section{Dasar Teori}

\subsection{Presipitasi}

Presipitasi terjadi setelah terbentuknya awan akibat dari peristiwa penguapan (evaporasi) pada permukaan ait di bumi. Presipitasi adalah nama umum dari uap yang mengkondensasi dan jatuh ke tanah dalam rangkaian proses siklus hidrologi. Presipitasi dapat berupa salju, hujan es, maupun air. Pada daerah tropis yaitu salah satunya Indonesia memiliki jenis presipitasi air yang dimanakan hujan. Tingkat curah hujan yang turun disuatu tempat sering dinamakan intensitas curah hujan. Satuan dalam menentukan intensitas curah hujan menggunakan $\mathrm{mm} / \mathrm{jam}$. Derajat curah hujan dapat digolongkan menjadi beberapa bagian sebagaimana pada tabel berikut. (Seyhan, 1990)

Berdasarkan tabel di atas dapat diketahui derajat hujan berdasarkan intensitas curah hujan yang terjadi dalam satuan $\mathrm{mm} /$ menit. Hujan yang sangat deras memiliki intensitas hujan lebih dari 1 $\mathrm{mm} /$ menit sedangkan yang sangat lemah memiliki intensitas kecil dari $0,02 \mathrm{~mm} / \mathrm{menit}$. Tingkat presipitasi berdasarkan ruang dan waktu memiliki keragamab. Terdapat beberapa factor yang mempengaruhi keragaman presipitasi. Berdasarkan Eagleson (1970) dalam (Seyhan, 1990) factor yang mempengaruhi keragaman presipitasi antara lain garis lintang, ketinggian tempat, jarak dari sumber air, posisi di dalam dan ukuran massa tanah benua atau daratan, arah angin yang umum 
(menuju atau menjauhi) terhadap sumber-sumber air, hubungannya dengan deretan gunung, dan suhu nisbi tanah dan samudera yang berbatasan.

Tabel 1. Derajat curah hujan dan intensitas curah hujan

\begin{tabular}{lll}
\hline \multicolumn{1}{c}{ Derajat hujan } & \multicolumn{1}{c}{$\begin{array}{c}\text { Intensitas curah } \\
\text { hujan }(\mathbf{m m} / \mathbf{m i n})\end{array}$} & \multicolumn{1}{c}{ Kondisi } \\
\hline $\begin{array}{l}\text { Hujan sangat lemah } \\
\text { Hujan lemah }\end{array}$ & $0,02-0,05$ & $\begin{array}{l}\text { Tanah agak basah atau dibasahi sedikit } \\
\text { Tanah menjadi basah semuanya, tetapi } \\
\text { sulit membuat model } \\
\text { Dapat dibuat model puddle dan bunyi } \\
\text { curah hujan kedengaran }\end{array}$ \\
Hujan normal & $0,05-0,25$ & $\begin{array}{l}\text { Air tergenang di seluruh permukaan } \\
\text { tanah dan bunyi keras hujan kedengaran } \\
\text { dari genangan } \\
\text { Hujan deras }\end{array}$ \\
$0,25-1$ & $>1$ & $\begin{array}{l}\text { Hujan seperti ditumpahkan, saluran dan } \\
\text { drainase meluap }\end{array}$ \\
Hujan sangat deras & &
\end{tabular}

Sumber: (Sosrodarsono, 2003)

\subsection{Pengukuran Presipitasi}

Terdapat beberapa alat pengukur presipitasi menurut (Seyhan, 1990) yaitu penakar hujan bukan pencatat dan penakar hujan otomatik (pencatat). Penggunaan Radar telah menjadi teknik pengambilan data dalam pengamatan hujan dan spasial dibeberapa Negara (Biggs, E.M., Atkinson, P.M., 2015).

\subsubsection{Penakar hujan baku (standar)}

Diameter lubang penakar hujan tipe ini ada beberapa macam yaitu 3,57 inci di Kanada, 5 inci di inggris, 8 atau 12 inci di AS. Berdasarkan spesifikasi WMO luasan 2 hingga $5 \mathrm{dm} 2$ merupakan luasan yang paling sesuai untuk lubang penakar hujan.

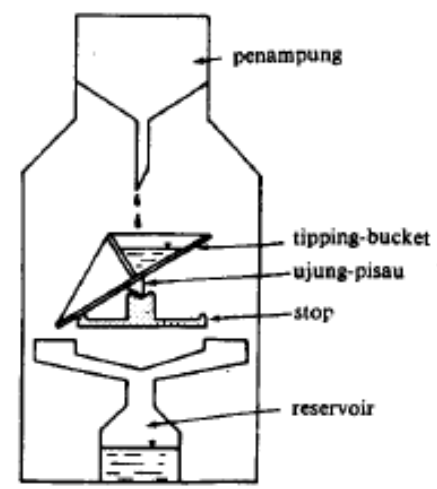

\section{Gambar 1. Bentuk Alat Ukur Hujan}

Stasiun penakar hujan memiliki karakteristik dalam merekam kejadian hujan di suatu tempat. Karakteristik stasiun hujan tersebut berdasarkan koordinat (latitude dan longitude), elevasi, jarak ke hilir, kemiringan dan aspek lokasi, hujan harian rata-rata, dan hujan musiman. (Johnson, 2018). 


\subsubsection{Analisis Data Hujan Rata-rata}

Dalam menentukan curah hujan yang berpengaruh dalam suatu Daerah Aliran Sungai (DAS) digunakan analisis hujan rata-rata. Dalam penentuan hujan rencana jumlah setasiun hujan sangat menentukan hasil prediksi hujan yang tepat. Pengaruh stasiun hujan secara regional sangat menentukan akurasi prediksi hujan (Johnson, 2018). Analisis data dalam penelitian ini menggunakan metode polygon thiessen. Metode ini sesuai untuk kawasan dengan jarak penakar hujan yang tidak merata dan memerlukan stasiun-stasiun pengamat dekat kawasan tersebut, serta panambahan suatu stasiun pengamat akan mengubah seluruh jaringan. Dalam metode ini tidak memperhitungakan kondisi topografi DAS. (Wijaya, 2016).

\subsection{Analisis Regresi dan Korelasi}

Analisis regresi digunakan untuk mempelajari dan mengukur hubungan statistic yang terjadi antara dua atau lebih variabel. Variabel yang akan diestimasi nilainya disebut variabel terikat, sedangkan variabel bebas ialah variabel yang diasumsikan memberikan pengaruh terhadap variasi variabel terikat. Analisis korelasi bertujuan untuk mengukur seberapa kuat atau derajat kedekatan, suatu relasi yang terjadi antar variabel. (Harinaldi, 2005)

\subsection{Model Analisis faktor}

Model analisis faktor adalah suatu model yang digunakan untuk mengetahui faktor " $\mathrm{x}$ " yang mempengaruhi antara dua peritiwa atau lebih. Model ini dapat memprediksi adanya hubungan antara dua kejadian atau lebih yang dipengaruhi suatu faktor tertentu yang menunjukkan pengaruhnya pada dua kejadian tersebut.

\section{Metode Penelitian}

Penelitian ini dilakukan dengan beberapa tahapan mulai dari proses pengumpulan data, distribusi data curah hujan dalam setiap satuan waktu, hingga melakukan analisis statistik model faktor dan ploting data kedalam grafik.

Analisis data dalam penelitian ini menggunakan analisis data uji korelasi linier. Ukuran korelasi dapat berupa koefisien determinasi dan koefisien korelasi. (Harinaldi, 2005). Koefisien determinasi $\left(r^{2}\right)$ didefinisikan sebagai perbandingan dari variasi.

$$
r^{2}=\frac{\sum(\hat{y}-\bar{y})^{2}}{\sum(y-\bar{y})^{2}}
$$

Atau

$$
r^{2}=\frac{a\left(\sum y\right)+b\left(\sum x y\right)-n(\bar{y})^{2}}{\sum(y)^{2}-n(\bar{y})^{2}}
$$

Nilai koefisien determinasi berkisar antara 0 (tidak ada relasi) dan 1 (relasi sempurna). Koefisien korelasi (r) mempunyai nilai yang merupakan akar dari koefisien deterninasi dan mempunyai tanda dengan ketentuan sebagai berikut. 


$$
r= \pm \sqrt{r^{2}}
$$

Tanda $\mathrm{r}$ mengikuti tanda konstanta $\mathrm{b}$ persamaan regresi ( $\mathrm{r}$ positif jika $\mathrm{b}$ positif dan $\mathrm{r}$ negative $\mathrm{b}$ negative). Dengan demikian nilai $r$ berkisar antara -1 sampai dengan +1 . Uji regresi yang digunakan dalam penelitian ini menggunakan rumus regresi sebagaimana berikut. Analisis regresi sederhana ini akan ditentukan persamaan yang menghubungkan dua variabel yang dapat dinyatakan sebagai bentuk persamaan pangkat satu. (Harinaldi, 2005)

$$
\hat{y}=a+b x
$$

Dimana:

$\hat{y} \quad=$ nilai estimate variabel terikat

a $\quad=$ titik potong garis regresi pada sumbu-y atau nilai estimate $\hat{y}$ bila $\mathrm{x}=0$

$\mathrm{b}=$ gradien garis regresi (perubahan nilai estimate $\hat{y}$ per satuan perubahan nilai $\mathrm{x}$ )

$\mathrm{x} \quad=$ nilai variabel bebas

Model analisis faktor dapat ditentukan dengan rumus:

$$
\begin{gathered}
X_{1}-\mu_{1}=l_{11} F_{1}+l_{12} F_{2}+\cdots+l_{1 m} F_{m}+\varepsilon_{1} \\
X_{2}-\mu_{2}=l_{21} F_{1}+l_{22} F_{2}+\cdots+l_{2 m} F_{m}+\varepsilon_{2} \\
\cdot \\
\cdot \\
X_{p}-\mu_{p}=l_{p 1} F_{1}+l_{p 2} F_{2}+\cdots+l_{p m} F_{m}+\varepsilon_{p}
\end{gathered}
$$

Atau secara ringkas sebagai berikut:

$$
X_{p x 1}-\mu_{p x 1}=l_{p x m} F_{m x 1}+\varepsilon_{p x 1}
$$

Dengan:

$\mathrm{L} \quad=$ matrik factor loading

$\mathrm{X}_{1} \quad=$ vektor acak yang memiliki $\mathrm{p}$ komponen ke-i

$\mu_{1} \quad=$ nilai rata-rata variabel ke-i

$F_{j} \quad=$ faktor bersamaan (common factor) yang ke-i, disebut juga faktor umum

$\varepsilon_{i} \quad=$ nilai sisa atau eror dari variabel ke-i, disebut juga faktor khusus

(Richard Jhonson,A.W \& Dean W, 2007)

Secara skema dapat dilihat pada gambar 2 berikut. 


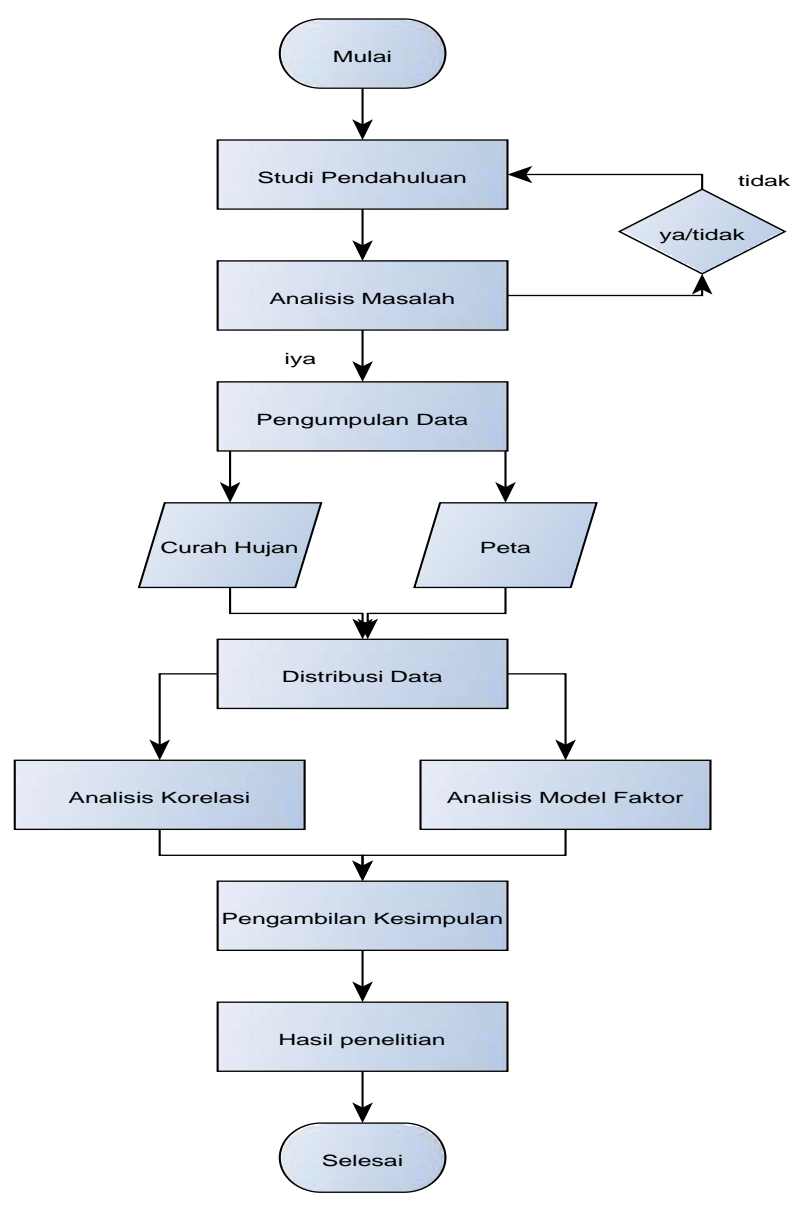

Gambar 2. Flowchart Penelitian

\section{Hasil dan Pembahasan}

Dalam penelitian ini dilakukan uji korelasi dari 5 stasiun hujan pada tahun 1998. Stasiun hujan yang diambil yaitu stasiun Doplang, Randu, Menden, Kedung, Japah,dan Sambong. Masingmasing stasiun hujan terdiri dari distribusi hujan sebagaimana pada gambar 3-6 berikut.
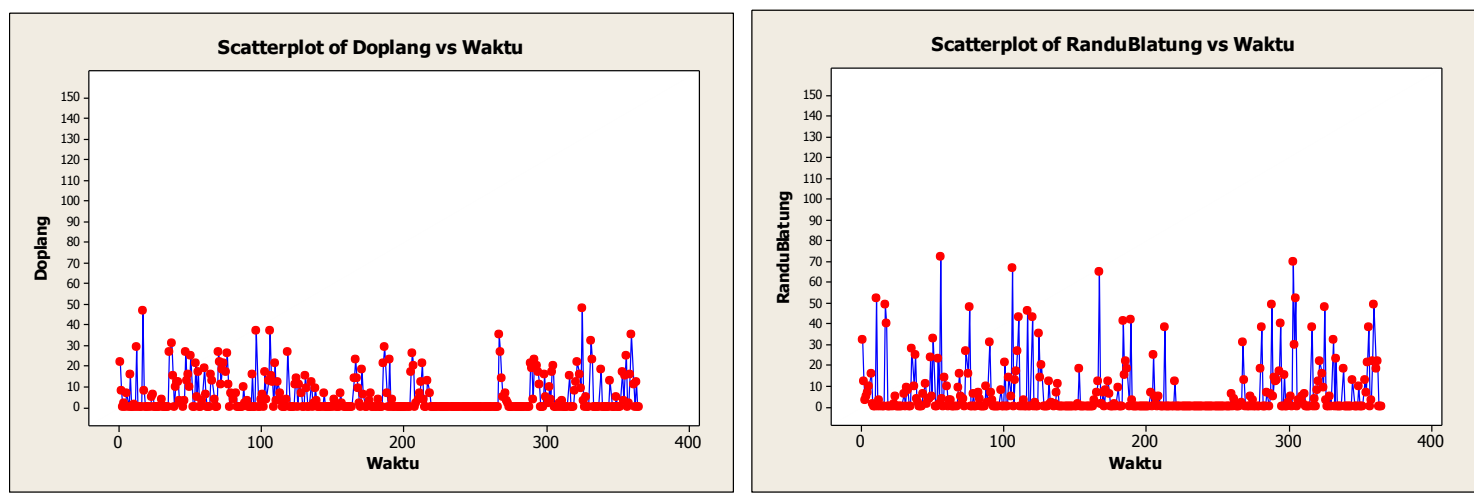

Gambar 3. Grafik Hujan Stasiun Doplang \& Blatung Tahun 1998 

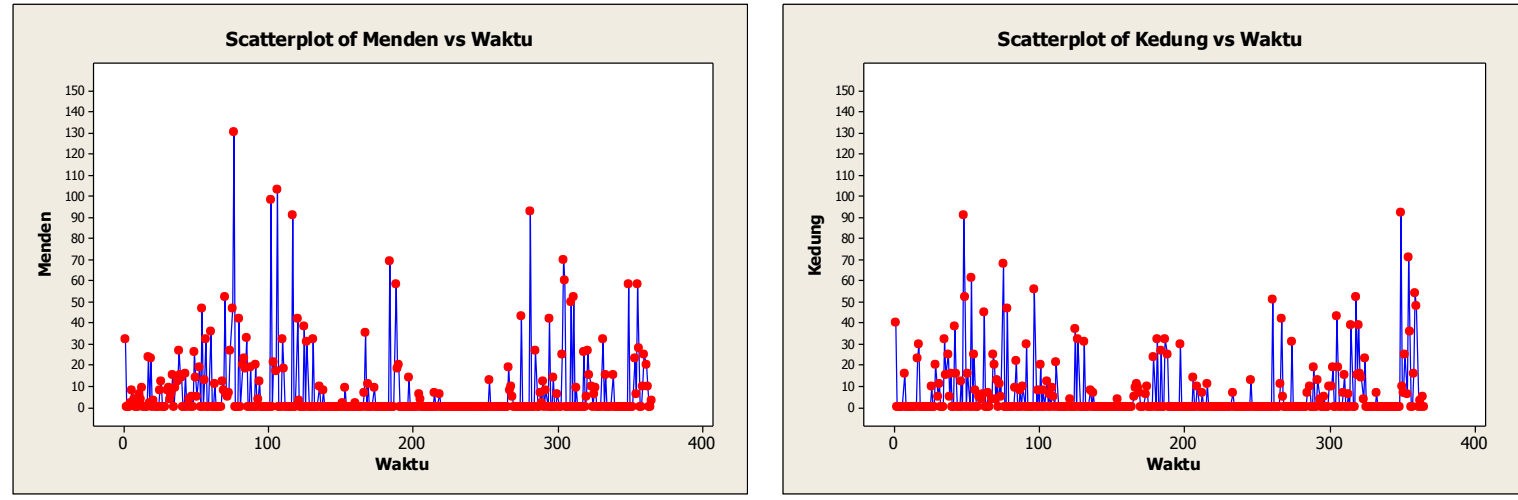

Gambar 4. Grafik Hujan Stasiun Menden \& Kedung Tahun 1998
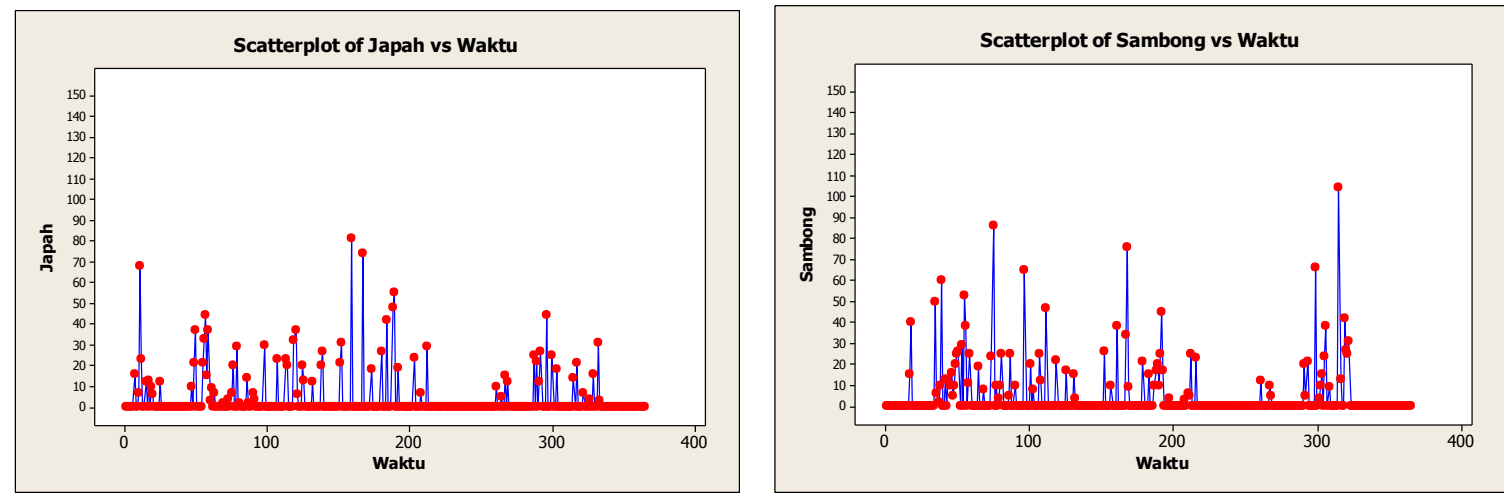

Gambar 5. Grafik Hujan Stasiun Japan \& Sambong Tahun 1998

Berdasarkan grafik hujan dari enam stasiun tersebut terlihat adanya perbedaan curah hujan yang terjadi pada tahun 1998. Perbedaan tersebut dapat lebih jelas lagi sebagaimana ditunjukkan pada gambar 6 berikut.

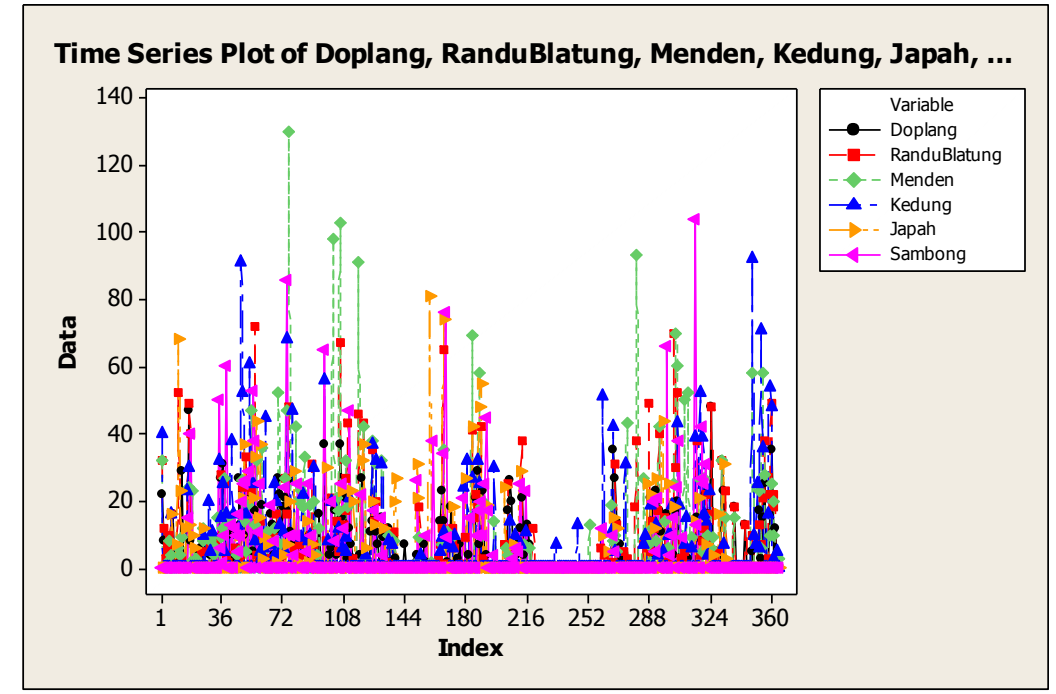

Gambar 6. Grafik Hujan Multiple dari Enam Stasiun Hujan Tahun 1998 
Gambar 3-6 di atas menunjukkan bahwa fluktuasi tinggi hujan antara masing-masing stasiun hujan memiliki sebaran yang sama. Hal ini menunjukkan bahwa kejadian hujan pada tahun 1998 terjadi memiliki fluktuasi yang sama dari berbagai tempat. Curah hujan yang terjadi menunjukkan bahwa hujan yang terjadi bersifat merata ke seluruh permukaan dari segi fluktuasi waktunya dan tingginya. Jumlah yang terjadi antara satu kejadian hujan yang dipengaruhi oleh tempat bukanlah dipengaruhi oleh kuantitas hujannya melainkan factor lain yang menyebabkannya berbeda. Dari penelitian ini dapat diprediksi terdapat beberapa factor yang mempengaruhi kuantitas hujan yang terjadi di berbagai tempat, antara lain:

1. Arah angin, lokasi terjadinya hujan baik tingkat kepadatan awan dan kuantitas presipitasi yang dihasilkan dipengaruhi oleh arah angin. Pergerakan awan hingga mencapai tingkat kejenuhan yang cukup dalam berubah menjadi presipitasi sangat dipengaruhi oleh arah angin.

2. Kecepatan angin, kecepatan pergerakan awan ditentukan pula dengan kecepatan angin yang membawanya.

3. Tekanan udara, tekanan udara diprediksi dapat meningkatkan tingkat kejenuhan awan untuk berubah menjadi presipitasi.

4. Ketinggian dari permukaan laut, ketinggian lokasi menentukan besar kecilnya tekanan udara yang ada pada lokasi tersebut.

\section{Tabel 2. Hasil Uji Korelasi}

\begin{tabular}{lcccc}
\hline & Doplang & Randublatung & Menden & Kedung \\
\hline Randublatung & 0.475 & - & - & - \\
Menden & 0.000 & - & - & - \\
\multirow{2}{*}{ Kedung } & 0.308 & 0.536 & - & - \\
& 0.000 & 0.000 & - & - \\
Japah & 0.246 & 0.130 & 0.190 & - \\
& 0.000 & 0.013 & 0.000 & - \\
Sambong & 0.056 & 0.274 & 0.128 & 0.018 \\
& 0.285 & 0.000 & 0.015 & 0.734 \\
\multirow{3}{*}{ Sambong } & 0.184 & 0.109 & 0.012 & 0.335 \\
\multirow{2}{*}{ Sel } & 0.000 & 0.037 & 0.814 & 0.000 \\
& Japah & - & - & - \\
& 0.169 & - & - & - \\
& 0.001 & - & - & \\
\hline
\end{tabular}

Berdasarkan hasil uji korelasi terlihat hubungan curah hujan antar stasiun nilai korelasi Pearson maksimum 0,536 pada stasiun Menden-Randu. Koordiinat lokasi stasiun randublatung $7^{\circ} 12^{\prime} 36^{\prime \prime} \mathrm{S}$ dan $111^{\circ} 22^{\prime} 48^{\prime \prime}$ E sedangkan menden $7^{\circ} 15^{\prime} 50^{\prime \prime} \mathrm{S}$ dan $111^{\circ} 28^{\prime} 48^{\prime \prime}$ E. Hubungan nilai korelasi Pearson minimum 0,012 yaitu pada stasiun sambong-menden. Koordinat lokasi stasiun sambong ialah $7^{\circ} 06^{\prime} 06^{\prime \prime} \mathrm{S}$ dan $111^{\circ} 33^{\prime} 55^{\prime \prime} \mathrm{E}$.

Korelasi kuat menunjukkan adanya factor yang sangat berpengaruh antara stasiun tersebut. Jarak antara stasiun sangat mempengaruhi kesamaan data hujan. Untuk itu, dalam mendapatkan data hujan yang lebih menyebar jarak antara stasiun perlu ditetapkan secara standarnya, sehingga dapat diketahui curah hujan rata-rata DAS secara lebih optimal dan efektif. 
Perhitungan dengan menggunakan model analysis factor menunjukkan terdapat 2 faktor yang mempengaruhi secara langsung dari distribusi data curah hujan pada 6 stasiun tersebut. Scree plot ditunjukkan pada gambar 9 berikut.

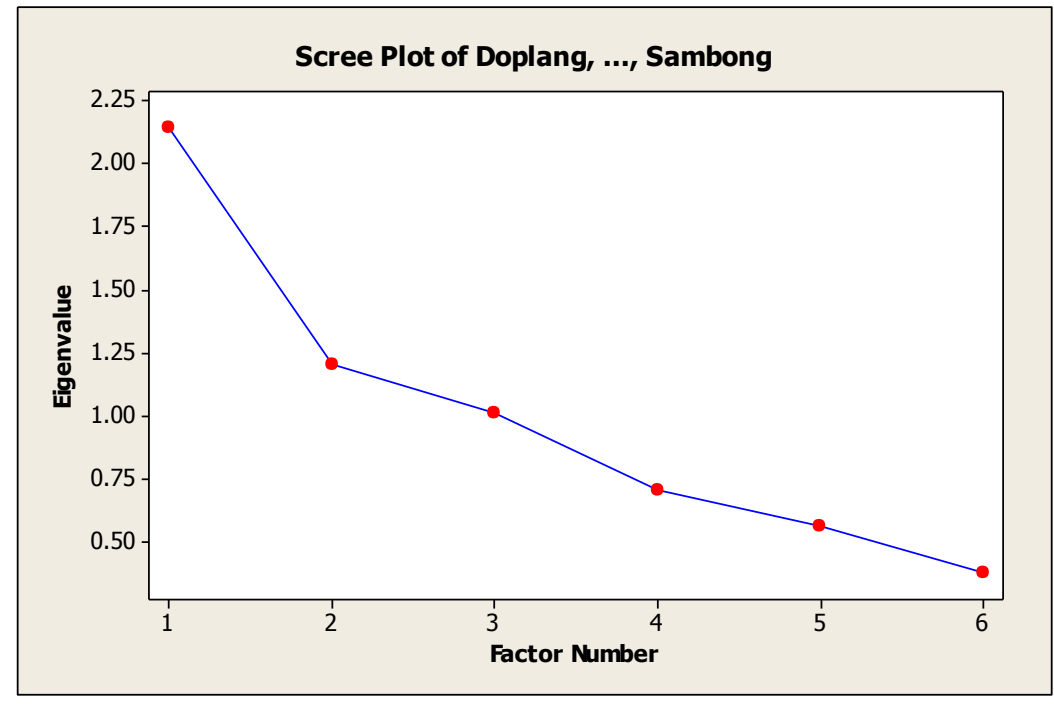

Gambar 7. Scree Plot

Berdasarkan gambar 9 di atas terdapat dua titik nilai Eigen di atas satu, dengan demikian jumlah factor yang diambil dalam hal ini adalah 2. Hasil model analysis factor ditunjukkan sebagai berikut.

Tabel 3. Kondisi Factor Loading tidak diputar dan Communalities

\begin{tabular}{llcc}
\hline Variabel (Stasiun Hujan) & Faktor 1 & Faktor 2 & Communality \\
\hline Doplang & 0.706 & 0.018 & 0.498 \\
Randublatung & 0.800 & 0.355 & 0.767 \\
Menden & 0.693 & 0.386 & 0.629 \\
Kedung & 0.480 & -0.612 & 0.605 \\
Japah & 0.371 & 0.057 & 0.141 \\
Sambong & 0.394 & -0.740 & 0.703 \\
Variance & 2.141 & 1.201 & 3.342 \\
\% Var & 0.357 & 0.200 & 0.557 \\
\hline
\end{tabular}

Besaran variance pada masing-masing factor menunjukkan bahwa variance factor 1 lebih besar dati factor 2. Sedangkan nilai dari factor loading pada factor 1 terbesar pada variabel stasiun randublatung yaitu 0,800 sedangkan pada factor 2 nilai terbesar berada pada variabel sambong yaitu $-0,740$. Tanda minus merupakan arah dari beban factor yang dimiliki masing-masing factor. Koefisien skor masing-masing factor dapat dilihat sebagai berikut.

Tabel 4. Koefisien Skor Faktor

\begin{tabular}{lcc}
\hline Variabel (Stasiun Hujan) & Faktor 1 & Faktor 2 \\
\hline Doplang & 0.330 & 0.015 \\
Randublatung & 0.374 & 0.295 \\
Menden & 0.323 & 0.322 \\
Kedung & 0.224 & -0.510 \\
Japah & 0.173 & 0.047 \\
Sambong & 0.184 & -0.616 \\
\hline
\end{tabular}


Berdasarkan hasil di atas diketahui factor 1 tidak memiliki nilai koefisien yang mencukupi yaitu > 0,5 namun bukan berarti pengaruhnya tidak ada akan tetapi kecil. Sedangkan pada factor 2 nilai koefisien skornya ada beberapa yang $>0,5$ yaitu pada variabel sambong dan kedung.

\section{Kesimpulan}

Penelitian ini menunjukkan beberapa hasil yaitu bahwa pola distribusi data curah hujan antar 6 stasiun memiliki pola yang sama sebagaimana ditunjukkan pada gambar 6. Koefisien korelasi yang dimiliki antara data pada masing-masing stasiun penakar hujan tidak ada yang lebih besar dari 0,6 sedangkan nilai maksimumnya berada pada 0,536 yaitu korelasi antara stasiun menden dan randu. Hasil uji korelasi menunjukkan hubungan antara kejadian hujan pada masing-masing stasiun kecil yang artinya hubungan kejadian hujan pada wilayah tersebut tidak begitu kuat. Sedangkan berdasarkan uji model faktor analisis menunjukkan terdapat 2 faktor yang mempengaruhi secara langsung antara stasiun tersebut. Faktor 1 memiliki nilai koefisien $<0,5$ sedangkan factor 2 memiliki 2 variabel yang nilainya $>0,5$ yaitu stasiun kedung dan sambong. Dengan demikian, factor 2 menunjukkan terdapat pengaruh langsung dari data hujan pada stasiun kedung dan sambong namun hubungan tersebut tergolong kecil . Berdasarkan perhitungan yang dilakukan menunjukkan bahwa curah hujan yang terjadi pada masing-masing wilayah tidak memiliki keterkaitan yang kuat antara satu dan lainnya, namun kejadian hujan yang terjadi memiliki pola distribusi yang sama. Dari hal ini memberikan informasi bahwa pola distribusi hujan setiap tahunnya sama disebabkan kejadian hujan mengikuti pola iklim dalam cakupan wilayah global walaupun letak stasiun hujan berbeda.

\section{Daftar Pustaka}

Bieger, K., Hörmann, G., Fohrer, N. (2014). Simulation of streamflow and sediment with the soil and water assessment tool in a data scarce catchment in the Three Gorges Region. J. Environment, 37.

Biggs, E.M., Atkinson, P.M. (2015). A comparison of gauge and radar precipitation data for simulating an extreme hydrological event in the Severn Uplands. UK Hydrology , 795-810.

Chin, D. A. (2018). On relationship between curve numbers and phi indices. elsevier, 187-195.

Harinaldi. (2005). Prinsip-prinsip Statistik untuk Teknik dan Sains. Jakarta: Erlangga.

Huang, C.L., Li, X., Lu, L. (2008). Retrieving soil temperature profile by assimilating MODIS LST products with ensemble Kalman filter. . Remote Sens. Environ. , 1320-1336.

Johnson, F. (2018). A comprehensive continent-wide regionalisation investigation for daily design rainfall. elsevier, 1-13.

Melching, C. S. (2018). Application of a water quality model for determining instream aeration station location and operational rules: A case study. elsevier , 8-16.

Richard Jhonson,A.W \& Dean W. (2007). Applied Multivariate Statistical Anlysis Edisi VI. New Jersey: Pretice-Hall International, Inc.

Seyhan, E. (1990). Dasar-dasar Hidrologi. Yogyakarta: Gadjah Mada University Press.

Sosrodarsono, S. (2003). Hidrologi untuk Pengairan. Jakarta: PT Pradnya Paramita. 
Wijaya, R. C. (2016). Bengawan Solo River Modelling to Create Map inundation of Flood. ARPN Journal , 1-11.

Xiao-lei Fu. (2018). Analysis of influence of observation operator on sequential data assimilation through soil temperature simulation with common land model. Water Science and Engineering , 196-204.

Xu, Z.-x. (2017). A distributed eco-hydrological model and its application. elsevier , 257-264. 